\title{
Communication
}

\section{Fast and Sensitive Bacteria Detection by Boronic Acid Modified Fluorescent Dendrimer}

\author{
Ayame Mikagi ${ }^{1}\left(\mathbb{D}\right.$, Riho Tsurufusa ${ }^{1}$, Yuji Tsuchido ${ }^{1,2} \mathbb{D}$, Takeshi Hashimoto ${ }^{1}$ (D) and Takashi Hayashita ${ }^{1, *(\mathbb{D})}$ \\ 1 Department of Materials and Life Sciences, Faculty of Science and Technology, Sophia University, \\ 7-1 Kioi-cho, Chiyoda-ku, Tokyo 102-8554, Japan; iris.14mls@eagle.sophia.ac.jp (A.M.); \\ r-tsuruhusa-r43@eagle.sophia.ac.jp (R.T.); y-tsuchido@aoni.waseda.jp (Y.T.); t-hasimo@sophia.ac.jp (T.H.) \\ 2 Department of Life Science and Medical Bioscience, School of Advanced Science and Engineering, \\ Waseda University (TWIns), 2-2 Wakamatsu-cho, Shinjuku-ku, Tokyo 162-8480, Japan \\ * Correspondence: ta-hayas@sophia.ac.jp; Tel.: +81-3-3238-3372
}

check for updates

Citation: Mikagi, A.; Tsurufusa, R.; Tsuchido, Y.; Hashimoto, T.; Hayashita, T. Fast and Sensitive Bacteria Detection by Boronic Acid Modified Fluorescent Dendrimer. Sensors 2021, 21, 3115. https:// doi.org/10.3390/s21093115

Academic Editor: Antonios Kelarakis

Received: 19 April 2021

Accepted: 27 April 2021

Published: 30 April 2021

Publisher's Note: MDPI stays neutral with regard to jurisdictional claims in published maps and institutional affiliations.

Copyright: (c) 2021 by the authors. Licensee MDPI, Basel, Switzerland. This article is an open access article distributed under the terms and conditions of the Creative Commons Attribution (CC BY) license (https:// creativecommons.org/licenses/by/ $4.0 /)$.

\begin{abstract}
This study reports a novel, fast, easy, and sensitive detection method for bacteria which is urgently needed to diagnose infections in their early stages. Our work presents a complex of poly(amidoamine) dendrimer modified by phenylboronic acid and labeled by a fluorescent dansyl group (Dan-B8.5-PAMAM). Our system detects bacteria in $20 \mathrm{~min}$ with a sensitivity of approximately $10^{4}$ colony-forming units $(\mathrm{CFU}) \cdot \mathrm{mL}^{-1}$. Moreover, it does not require any peculiar technical skills or expensive materials. The driving force for bacteria recognition is the binding between terminal phenylboronic acids on the probe and bacteria's surface glycolipids, rather than electrostatic interactions. The aggregation caused by such binding reduces fluorescence. Even though our recognition method does not distinguish between live or dead bacteria, it shows selective antibacterial activity towards Gram-negative bacteria. This study may potentially contribute a new method for the convenient detection and killing of bacteria.
\end{abstract}

Keywords: bacteria detection; E. coli; S. aureus; dendrimer; phenylboronic acid; fluorescence measurement

\section{Introduction}

In recent years, development of multidrug-resistant bacteria is becoming a global issue $[1,2]$. Since the abuse of antibiotics is a major reason for the genetic mutation, more specific dosing is urgently needed [3,4]. In order to detect and diagnose infections in their early stages, species-specific recognition of bacteria is particularly important. However, currently, a major recognition system for bacteria would need expensive reagents [5,6] or traditional cultivation for several days [7]. Unfortunately, to the best of our knowledge, a fast, easy, and sensitive detection method for bacteria has not been established yet in clinical practice.

The problem has attracted the interest of many researchers, and various nanomaterials conjugated with recognition elements which can recognize bacteria [8,9] or microbial agents [10] have been reported. For instance, matrix-assisted laser desorption ionization time-of-flight mass spectrometry (MALDI-TOF-MS) [11] and the disposable colorimetric sensor array [12] shortened the identification time to a few hours. An immunosensor [13] or polymerase chain reaction (PCR) [14] is also a sensitive and specific detection method for bacteria, but it requires expensive instruments and careful sample preparation, and it takes several hours to provide results. As another example, though an antibody-based system such as the enzyme-linked immunosorbent assay (ELISA) does not need a skilled researcher or a long period of time, it costs money because it uses expensive antibodies [7,15]. In the same manner as many biological challenges [16,17], nanoprobes with binding sites as a recognitive function represent a potential solution. For instance, nanoprobes with dipicolylamine for Staphylococcus aureus [18] or Escherichia coli [19,20], mannose towards E. coli [21,22], cationic amine groups [23,24] and vancomycin [25] for various species, or 
cell wall binding domains for corresponding bacteria [26] were developed to attempt instant and sensitive detection of bacteria. Many laboratories have focused on bacteria detection by convenient optical measurements, such as luminescence changing [27,28]. From the perspective of surface glycolipids on bacteria which show species specificity, the detection of saccharides might be a significant strategy. Phenylboronic acid is widely applied for saccharide recognition because it is known that phenylboronic acid forms a bond with the cis-diol sites of saccharide [29,30]. Previously, we reported the selective recognition of Gram-positive bacteria by a poly(amidoamine) dendrimer chemically modified by phenylboronic acid (B-PAMAM) [31]. Phenylboronic acids of B-PAMAM interacted with the surfaces of bacteria and formed aggregations which could be observed by the naked eye. However, the limit of detection (LOD) calculated from turbidity measurements was $6.4 \times 10^{6} \mathrm{CFU} \cdot \mathrm{mL}^{-1}$. This value was far from the clinical requirement, which is approximately $10^{3}$ or $10^{5} \mathrm{CFU} \cdot \mathrm{mL}^{-1}[32,33]$. Moreover, the biological activity of B-PAMAM and the status of bacteria (live or dead) have not been investigated at all. This study aims to improve the sensitivity of fluorescence measurement and investigate the antibacterial activity of dendrimers. A dansyl group (Dan) was introduced to B-PAMAM as a fluorescence label $[34,35]$ and different kinds of dendrimers were prepared depending on the number of phenylboronic acid groups attached on their surfaces (Figure 1). Fluorescent measurements carried out by Dan-B-PAMAMs proved to be fast, easy, and sensitive.

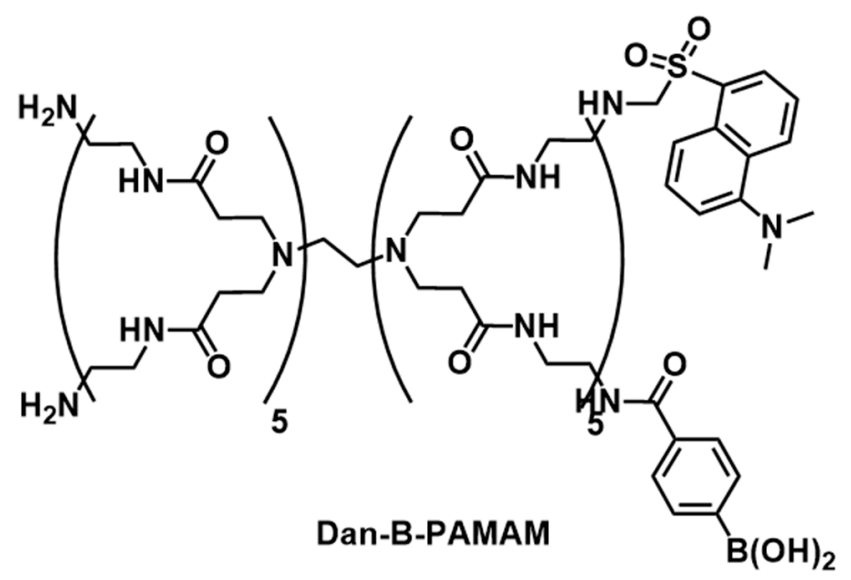

Figure 1. Structure of Dan-B-PAMAM.

\section{Materials and Methods}

\subsection{Reagents and Apparatus}

\subsubsection{Reagents}

All reagents and solvents were obtained from commercial suppliers and used without further purification, unless otherwise stated. Firstly, 4-Carboxyphenylboronic acid (354-36403), triethylamine (202-02641), sodium chloride (191-01665), and agar (018-15811) were purchased from FUJIFILM Wako Pure Chemical Corporation (Osaka, Japan). Dimethylsulfoxide luminasol (DMSO-Lu, LU08), propidium iodide solution (PI, P378), 3,6-bis (dimethylamino)acridine hydrochloride solution ( $\mathrm{AO}, \mathrm{A} 430)$, ethidium bromide solution (EB, E272), 3-(4,5-dimethyl-2-thiazolyl)-2,5-diphenyl-2H-tetrazolium bromide (MTT, M009), and $4^{\prime}$,6-diamidino-2-phenylindole dihydrochloride n-hydrate (DAPI, D523) were purchased from DOJINDO LABORATORIES (Kumamoto, Japan). Moreover, 5-(Dimethylamino) naphthalene-1-sulfonyl chloride (dansyl chloride, D0656) and 4-(4,6-dimethoxy1,3,5-triazin2-yl)-4-methylmorpholinium chloride (DMT-MM, D2919) were purchased from Tokyo Chemical Industry Co. Ltd. (Tokyo, Japan). Methanol (25183-70), methanol-d $\mathrm{d}_{4}$ (99.8\%, 25183-70), and $\mathrm{D}_{2} \mathrm{O}(99.8 \%, 10086-23)$ were purchased from Kanto Chemical Co. Inc. (Tokyo, Japan). Poly(amidoamine) (PAMAM) dendrimer, ethylenediamine core, generation 3.5 (142430-2.5G) and 4.0 (412449-10G) solutions were purchased from Sigma-Aldrich Japan Co. LLC. (Tokyo, Japan). Bacto yeast extract (212750) and bacto tryptone (211705) were pur- 
chased from Nippon Becton, Dickinson Co., Ltd. (Tokyo, Japan). Phosphate-buffered saline (PBS, 2101) was purchased from Cell Science \& Technology Institute Inc. (Miyagi, Japan). Water was doubly distilled and deionized using a Milli-Q water system (WG222, Yamato Scientific Co., Ltd., Tokyo, Japan and Milli-Q Advantage, Merck Millipore, Burlington, MA, USA) before use.

\subsubsection{Apparatus}

${ }^{1} \mathrm{H}$ Nuclear magnetic resonance (NMR) spectra were recorded on a JEOL JNM-ECA 500 spectrometer $(500 \mathrm{MHz})$ by JEOL (Tokyo, Japan) at $300 \mathrm{~K}$ or a Bruker Avance III HD $400 \mathrm{MHz}$ at $298 \mathrm{~K}$ in deuterated solvents. All $\mathrm{pH}$ values were recorded using a Horiba F-52 pH meter (HORIBA Ltd., Kyoto, Japan). Ultraviolet-visible (UV-vis) absorption spectra were measured using a Hitachi V-570 or V-760 UV-vis spectrophotometer (Hitachi HighTechnologies Co., Tokyo, Japan) equipped with a Peltier thermocontroller and a $10 \mathrm{~mm}$ quartz cell. Fluorescence spectra were measured using a HITACHI F-7000 fluorescence spectrophotometer (Hitachi High-Technologies Co., Tokyo, Japan) equipped with a Peltier thermocontroller and a $10 \mathrm{~mm}$ quartz cell. Zeta potential measurements were carried out at $25{ }^{\circ} \mathrm{C}$ using a Zetasizer Nano ZS (Malvern Instruments Ltd., Malvern, Worcestershire, UK). Samples were shaken by MALTI CHAKER MS-300 (AS ONE Co., Osaka, Japan). Centrifugation was conducted using CF15RN (Hitachi High-Technologies Co., Tokyo, Japan). Nanoprobes were lyophilized by EYELA FDU-1200 (TOKYO RIKAKIKAI Co. LTD., Tokyo, Japan).

\subsection{Preparation of Dendrimer Probes}

\subsubsection{Preparation of PAMAM( $\left.\mathrm{NH}_{2}\right)$}

PAMAM(G4) dendrimer dissolved in methanol $(1.0 \mathrm{~mL}, 5.7 \mu \mathrm{mol})$ was transferred into a Spectra/Por 6 dialysis bag (MW cutoff $=1000$, Repligen, MA, USA) and dialyzed against distilled water. The solution was lyophilized for 2 days to produce a white powder (63.7 $\mathrm{mg}, 78 \%)$.

\subsubsection{Preparation of PAMAM(COOH)}

PAMAM(G3.5) dendrimer dissolved in methanol $(1.5 \mathrm{~mL}, 8.6 \mu \mathrm{mol})$ was transferred into a Spectra/Por 6 dialysis bag (MW cutoff $=1000$, Repligen, MA, USA) and dialyzed against distilled water. The solution was lyophilized for 2 days to give a white powder (84.9 mg, 70\%).

\subsubsection{Synthesis of Dan-PAMAM}

PAMAM(G4) dendrimer dissolved in methanol (4.5 mL, $25.7 \mu \mathrm{mol}), 5$-(dimethylamino) naphthalene-1-sulfonyl chloride $(41.39 \mathrm{mg}, 153 \mu \mathrm{mol})$, and triethylamine $(1.172 \mathrm{~g}, 11.6 \mathrm{mmol})$ was dissolved in $30 \mathrm{~mL}$ of methanol followed by reflux at $60{ }^{\circ} \mathrm{C}$ for $72 \mathrm{~h}$. The mixture was transferred into a Spectra/Por 6 dialysis bag (MW cutoff $=1000$, Repligen, MA, USA) and dialyzed against methanol and distilled water. The resultant solution was lyophilized to obtain a yellow solid ( $288 \mathrm{mg}, 72.9 \%)$. The structure and the number of dansyl substitutions were confirmed by ${ }^{1} \mathrm{H}$ NMR spectra (Figure S1).

\subsubsection{Synthesis of Dan-B-PAMAMs}

Dan-PAMAM, 4-carboxyphenylboronic acid, and 4-(4,6-dimethoxy-1,3,5-triazin-2-yl)4-methylmorpholinium chloride were dissolved in methanol $(20 \mathrm{~mL})$ and stirred at room temperature for 2 days (Table 1). The reaction mixture was transferred into a Spectra/Por 6 dialysis bag (MW cutoff $=1000$, Repligen, MA, USA) and dialyzed against methanol and distilled water. The solution was then lyophilized to give a pale-yellow solid, followed by ${ }^{1} \mathrm{H}$ NMR measurement. The number of phenylboronic acid substitutions was calculated from the peak area of ${ }^{1} \mathrm{H}$ NMR spectra (Figures S3-S5). It was noted that Dan-B3-PAMAM was obtained from Dan-PAMAM which was modified by six dansyl groups (Figure S2). 
Table 1. Syntheses of Dan-B-PAMAM dendrimers.

\begin{tabular}{|c|c|c|c|c|c|}
\hline & Dan-PAMAM & Phenylboronic Acid & DMT-MM & $\begin{array}{c}\text { The Number of } \\
\text { Phenylboronic Acid } \\
\text { Substitutions }\end{array}$ & Yield \\
\hline Dan-B3-PAMAM & $91.62 \mathrm{mg}$ & $\begin{array}{c}5.84 \mathrm{mg} \\
(35.2 \mu \mathrm{mol})\end{array}$ & $\begin{array}{c}48.71 \mathrm{mg} \\
(176.2 \mu \mathrm{mol})\end{array}$ & 3 & $\begin{array}{c}31.6 \mathrm{mg} \\
(23 \%)\end{array}$ \\
\hline Dan-B4-PAMAM & $43.25 \mathrm{mg}$ & $\begin{array}{c}1.89 \mathrm{mg} \\
(11.4 \mu \mathrm{mol})\end{array}$ & $\begin{array}{c}15.77 \mathrm{mg} \\
(57.03 \mu \mathrm{mol})\end{array}$ & 4 & $\begin{array}{c}47.4 \mathrm{mg} \\
(86 \%)\end{array}$ \\
\hline Dan-B8.5-PAMAM & $43.93 \mathrm{mg}$ & $\begin{array}{c}4.71 \mathrm{mg} \\
(28.4 \mu \mathrm{mol})\end{array}$ & $\begin{array}{c}42.99 \mathrm{mg} \\
(155.5 \mu \mathrm{mol})\end{array}$ & 8.5 & $\begin{array}{c}30.2 \mathrm{mg} \\
(46 \%)\end{array}$ \\
\hline
\end{tabular}

\subsection{Bacteria Detection}

\subsubsection{Culturing of Bacteria}

Lysogeny broth (LB) medium was prepared using $2 \mathrm{~g}$ of bacto tripton, $1 \mathrm{~g}$ of bacto yeast extract, and $2 \mathrm{~g}$ of $\mathrm{NaCl}$ in $200 \mathrm{~mL}$ distilled water. S. aureus IAM1011 and E. coli K12W3110 were cultured at $37^{\circ} \mathrm{C}$ overnight on LB agar plates which contained mixtures of $200 \mathrm{~mL}$ of LB medium and $3 \mathrm{~g}$ of agar. The obtained colony was isolated and cultured in LB medium at $37^{\circ} \mathrm{C}$ overnight. The solution was centrifuged $(10,000 \mathrm{rpm}, 1 \mathrm{~min})$ and washed with distilled water. The procedure was repeated twice to remove the medium. After washing, it was centrifuged once more and washed with PBS buffer. The concentrations of the bacterial suspensions were adjusted by measuring $\mathrm{OD}_{600}$ after vortex mixing. Calculation index is shown below.

- S. aureus: $\mathrm{OD}_{600}=1.0, \mathrm{CFU}=4.5 \times 10^{8} \mathrm{~mL}^{-1}$

- E. coli: $\mathrm{OD}_{600}=1.0, \mathrm{CFU}=1.0 \times 10^{9} \mathrm{~mL}^{-1}$

Cultured bacteria were subjected to fluorescence microscopy imaging, optical measurements, and zeta potential measurements. For fluorescence microscopy, DAPI, EB, AO or PI solution was mixed to cultured bacteria in PBS buffer and washed to displace the dye. Fluorescence intensity and zeta potential were obtained at room temperature, while $\mathrm{UV}$-vis spectra and $\mathrm{OD}_{600}$ were measured at $25^{\circ} \mathrm{C}$.

\subsubsection{Detection Method without Filtration}

Dan-B3-PAMAM $(1.5 \mathrm{~mL}, 6.6 \mu \mathrm{M})$ and S. aureus in PBS buffer $\left(1.5 \mathrm{~mL}, 2.0 \times 10^{5}\right.$ to $2.0 \times 10^{8} \mathrm{CFU} \cdot \mathrm{mL}^{-1}$ ) were mixed for $10 \mathrm{~min}$ at $2000 \mathrm{rpm}$ followed by fluorescence and turbidity measurements with or without $10 \mathrm{~min}$ standing.

\subsubsection{Optimized Detection Method with Filtration}

Dan-PAMAM, Dan-B4-PAMAM, or Dan-B8.5-PAMAM $(1.5 \mathrm{~mL}, 6.6 \mu \mathrm{M})$ and S. aureus $\left(1.5 \mathrm{~mL}, 2.0 \times 10^{4}\right.$ to $\left.2.0 \times 10^{9} \mathrm{CFU} \cdot \mathrm{mL}^{-1}\right)$ or E. coli $\left(1.5 \mathrm{~mL}, 2.0 \times 10^{4}\right.$ to $\left.2.0 \times 10^{8} \mathrm{CFU} \cdot \mathrm{mL}^{-1}\right)$ in PBS buffer were mixed for $10 \mathrm{~min}$ at $2000 \mathrm{rpm}$. The resultant solution was left to stand for $10 \mathrm{~min}$ and filtered (the diameter of pores was $0.2 \mu \mathrm{m}$ ), followed by fluorescence measurement. Then, $1.5 \mathrm{~mL}$ of PBS buffer was selected as a bacterial control sample and subjected to the same procedure. Reproducibility was confirmed by repeating three or more times.

\subsubsection{MTT Assay}

Bacteria $\left(750 \mu \mathrm{L}, 6.0 \times 10^{8} \mathrm{CFU} \cdot \mathrm{mL}^{-1}\right)$ and probe solution $(750 \mu \mathrm{L}, 6.6 \mu \mathrm{M})$ or PBS buffer $(750 \mu \mathrm{L})$ were mixed and shaken for $10 \mathrm{~min}, 2000 \mathrm{rpm}$ to form complex. After the centrifugation of the solution, the supernatant was removed from complex. LB medium $(1 \mathrm{~mL})$ and MTT solution $\left(100 \mu \mathrm{L}, 5 \mathrm{mg} \cdot \mathrm{mL}^{-1}\right)$ were mixed with the complex, followed by incubation at $37^{\circ} \mathrm{C}$ for $20 \mathrm{~min}$ [36]. After incubation, the reaction mixture was centrifugated and supernatant was displaced from the precipitates. The resultant solution was added to $1 \mathrm{~mL}$ of DMSO-Lu. DMSO-Lu destroyed the bacteria's membrane and quenched 
the reaction of MTT by mixing. The absorbance of dissolved formazan was measured $\left(\lambda_{\mathrm{abs}}=560 \mathrm{~nm}\right)$ and PBS samples were used as controls.

\section{Results and Discussion}

\subsection{Recognition Mechanism by Chemically Modified PAMAM Dendrimers}

The surface properties of various PAMAM dendrimers were investigated by zeta potential measurement to give information about the interaction with bacteria [37]. For each sample, the measurements were repeated three times for $\operatorname{PAMAM}\left(\mathrm{NH}_{2}\right)$ and PA$\mathrm{MAM}(\mathrm{COOH})$ and six times for other PAMAMs with terminal dansyl groups. The average values are summarized in Table 2.

Table 2. Zeta potential of PAMAM dendrimers.

\begin{tabular}{cc}
\hline Probe & Zeta Potential $(\mathrm{mV})$ \\
\hline PAMAM(COOH) & $-3.58 \pm 2.08$ \\
PAMAM(NH $\left.{ }_{2}\right)$ & $3.42 \pm 1.54$ \\
Dan-PAMAM & $13.78 \pm 1.27$ \\
Dan-B4-PAMAM & $6.57 \pm 5.58$ \\
Dan-B8.5-PAMAM & $4.30 \pm 4.34$ \\
\hline
\end{tabular}

The results of PAMAM $\left(\mathrm{NH}_{2}\right)$ and $\operatorname{PAMAM}(\mathrm{COOH})$ showed that the amine group of $\operatorname{PAMAM}\left(\mathrm{NH}_{2}\right)$ was protonated and carboxylic acid on PAMAM $(\mathrm{COOH})$ was deprotonated at $\mathrm{pH}$ 7.4. The measurements of Dan-PAMAM, Dan-B4-PAMAM, and Dan-B8.5-PAMAM showed a positively charged surface. The value of their zeta potential decreased as the substituent number of phenylboronic acids increased. Such results suggested that phenylboronic acid forms a tetrahedral boronate at $\mathrm{pH} \mathrm{7.4,} \mathrm{and} \mathrm{it} \mathrm{causes} \mathrm{the} \mathrm{neutralization} \mathrm{of}$ amine's positive charges, weakening their electrostatic interactions. Since it is well known that the surface of bacteria is negatively charged [38], positively charged probes could form minute aggregates by electrostatic interaction with bacteria. Fluorescent microscope observations clearly confirmed this hypothesis (Figure 2A-D).

The microscopy images showed that the solution of PBS buffer as a control sample and PAMAM $(\mathrm{COOH})$ did not produce any aggregates, in contrast to other probes (Figure 2A,B). Among probes modified by the dansyl group, images of dansyl and EB describing the existence of bacteria were overlapped (Figure $2 \mathrm{C}, \mathrm{D}$ ). The results indicated that probes were able to form aggregates with bacteria. Even though PAMAM $\left(\mathrm{NH}_{2}\right)$ and Dan-PAMAM had not been functionalized with phenylboronic acid groups, they formed minute aggregates with both $S$. aureus and E. coli. Such aggregations suggested that electrostatic bonding between positively charged PAMAM $\left(\mathrm{NH}_{2}\right)$ or Dan-PAMAM and negatively charged bacteria was sufficient for the success of their interactions, and the implementation of phenylboronic acids was not necessary for forming minute aggregates. In terms of Dan-B4-PAMAM and Dan-B8.5-PAMAM, aggregations were observed as well and Dan-B8.5-PAMAM gave much larger aggregates than Dan-B4-PAMAM. The difference can be explained as follows. The bonding between terminal phenylboronic acids and glycolipids on the bacteria surface is the critical driving force of the aggregation, rather than electrostatic interaction. It was suggested that the more phenylboronic acid groups bonded on dendrimers, the more bacteria interacted and formed large aggregates.

\subsection{Development of Sensitive Bacterial Recognition}

Dan-B3-PAMAM was used as a test probe to develop a novel sensitive method using fluorescence measurements (Figure 3A,B). In this study, fluorescent aggregates between probes and bacteria were observed after being mixed for only $10 \mathrm{~min}$. The transformation of fluorescence intensity after the formation of aggregates is a desirable index. Fluorescence and $\mathrm{OD}_{600}$ measurements of supernatants were carried out twice: after mixing and after standing for $10 \mathrm{~min}$ [31]. 
(A)

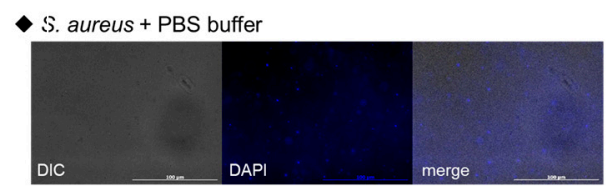

- S. aureus + PAMAM $\left(\mathrm{NH}_{2}\right)$

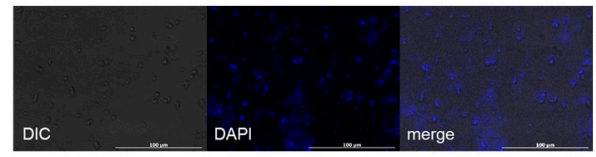

- S. aureus + PAMAM(COOH)

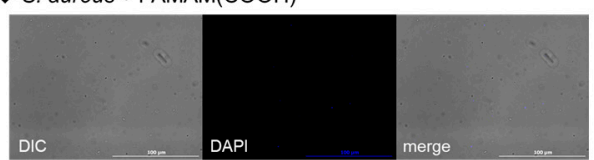

(C)

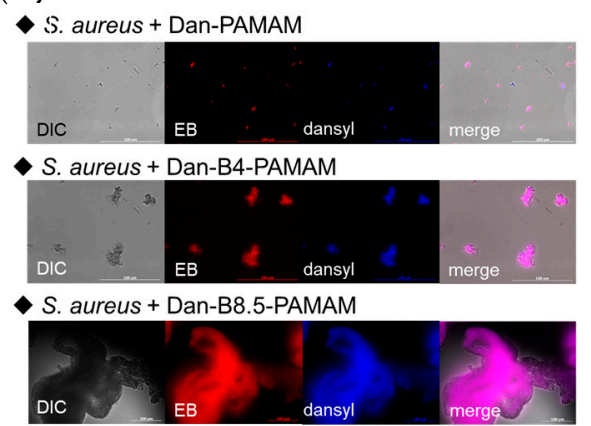

(B)

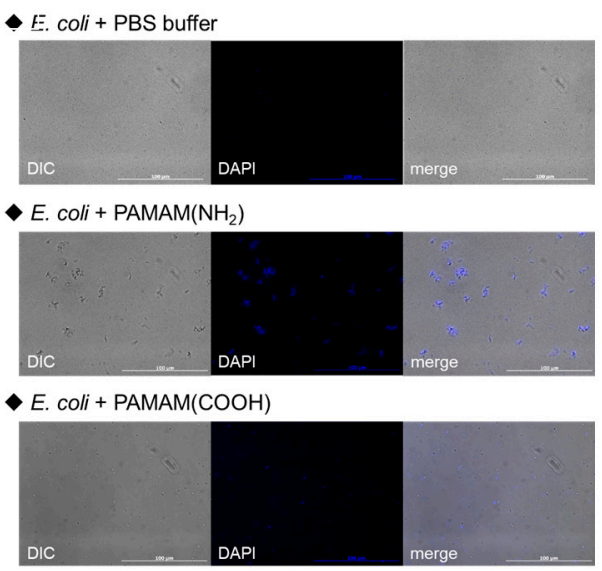

(D)

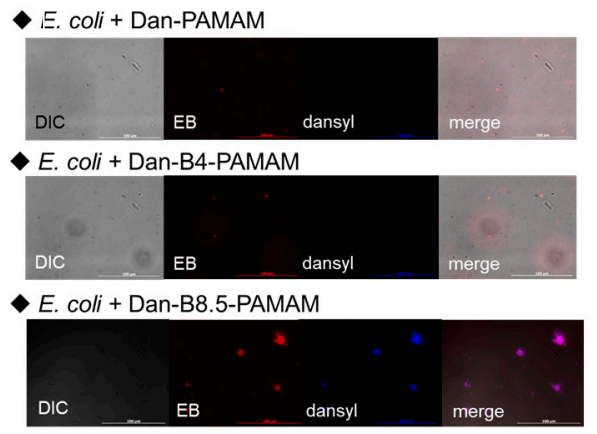

Figure 2. Fluorescence microscopy images of $S$. aureus or E. coli with dendrimers ( $\mathrm{pH}=7.4$ adjusted by PBS buffer, (dendrimer) $=3.3 \mu \mathrm{M})$. (A,B) bacteria were stained with DAPI, $\lambda_{\mathrm{ex}}=360 \mathrm{~nm}, \mathrm{OD}_{600}$ of bacteria $=0.3$. $(\mathbf{C}, \mathbf{D})$ bacteria were stained with $\mathrm{EB}, \mathrm{EB}: \lambda_{\mathrm{ex}}=525 \mathrm{~nm}$, probe: $\lambda_{\mathrm{ex}}=330 \mathrm{~nm}$. (bacteria) $=10^{8} \mathrm{CFU} \cdot \mathrm{mL}^{-1}$.

(A)

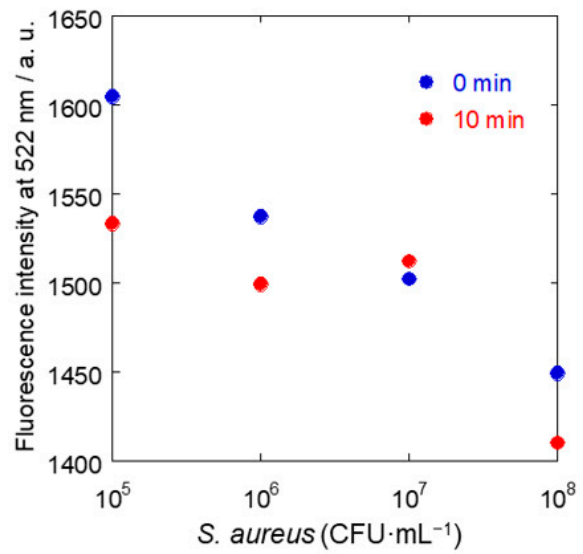

(B)

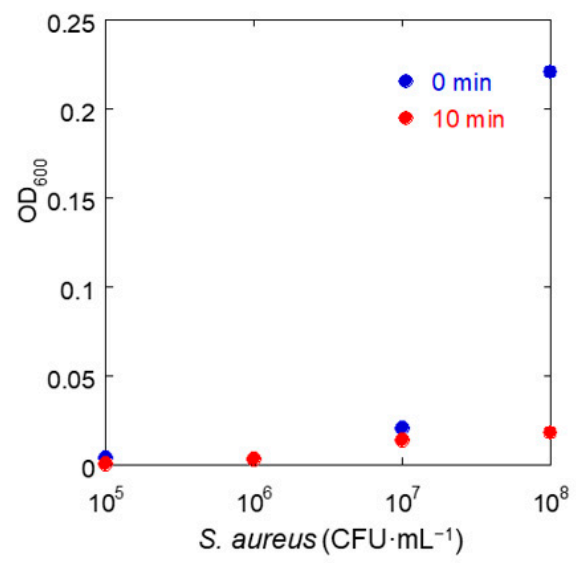

Figure 3. Fluorescence and turbidity measurements of Dan-B3-PAMAM in PBS buffer at $\mathrm{pH} 7.4$ $\left((\right.$ Dan-B3-PAMAM $)=0.1 \mathrm{mg} \cdot \mathrm{mL}^{-1},($ S aureus $\left.)=10^{5}-10^{8} \mathrm{CFU} \cdot \mathrm{mL}^{-1}\right)$. (A) Fluorescence intensity at $522 \mathrm{~nm}\left(\lambda_{\mathrm{ex}}=330 \mathrm{~nm}\right)$. (B) $\mathrm{OD}_{600}$ of $0 \mathrm{~min}$ and $10 \mathrm{~min}$.

Unfortunately, fluorescence intensity did not decrease significantly in all samples (Figure $3 \mathrm{~A}$ ). Only the turbidity of the $10^{8} \mathrm{CFU} \cdot \mathrm{mL}^{-1}$ concentration changed significantly after standing for $10 \mathrm{~min}$ (Figure 3B). Minute aggregations and bacteria floating in the sample solution caused light scattering and affected the measurements. Therefore, a protocol for deleting floating particles is deemed to be necessary to improve sensitivity. 
Based on this hypothesis, minute compounds were removed by filtration (the diameter of pores was $0.2 \mu \mathrm{m}$ ) after standing for $10 \mathrm{~min}$, and fluorescent measurements were conducted only for the filtrate solution (Figure $4 \mathrm{~A}, \mathrm{~B}$ ). A mixture of various probes and PBS buffer was prepared as a negative control (Figure $4 \mathrm{~A}$ ).

(A)

\begin{tabular}{|c|c|}
\hline probe & $F_{\text {none }}$ Average \\
\hline Dan-PAMAM & $1442 \pm 28.59$ \\
\hline Dan-B4-PAMAM & $1213 \pm 23.52$ \\
\hline Dan-B8.5-PAMAM & $1240 \pm 14.06$ \\
\hline
\end{tabular}

(B)

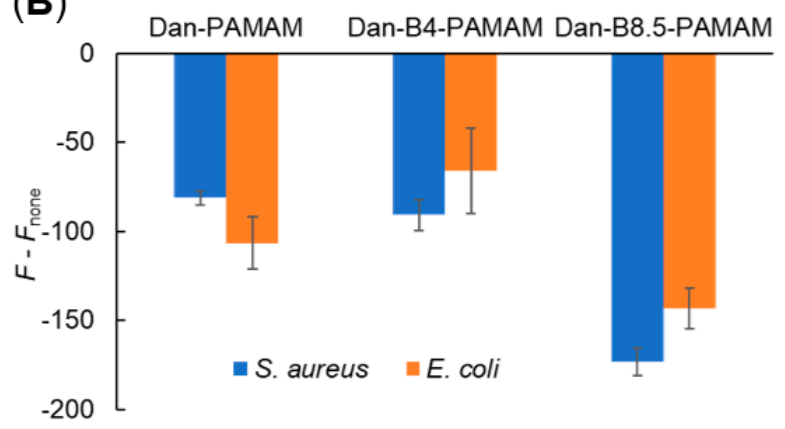

Figure 4. Fluorescence measurements of Dan-PAMAMs. (A) Average of fluorescent intensity of probes in PBS buffer adjusted at pH $7.4\left(\lambda_{\mathrm{ex}}=330 \mathrm{~nm}, \lambda_{\mathrm{em}}=522 \mathrm{~nm}\right.$, (probe) $\left.=3.3 \mu \mathrm{M}, \mathrm{n} \geq 3\right)$. (B) Decrease in fluorescence intensity compared with $F_{\text {none }}\left(\lambda_{\mathrm{ex}}=330 \mathrm{~nm}, \lambda_{\mathrm{em}}=522 \mathrm{~nm}\right)$, (probe) $=3.3 \mu \mathrm{M}$, (bacteria) $=10^{8} \mathrm{CFU} \cdot \mathrm{mL}^{-1}, \mathrm{n} \geq 3$.

Measurements carried out after filtration showed good reproducibility (Figure 4A) and the reduction of fluorescent intensity too (Figure 4B). In particular, the Dan-B8.5PAMAM sample produced visible aggregates and a notable reduction in terms of intensity change. The reduction of fluorescence was also confirmed in the Dan-PAMAM solution, which should not recognize bacteria. The change could be explained by the elimination of minute aggregations formed by electrostatic interactions. According to the result of the Dan-B4-PAMAM sample, it was suggested that the recognition power was due to the number of phenylboronic acids of dendrimers able to bind with saccharide sites on the bacteria surface.

Afterwards, the recognition capability of Dan-B8.5-PAMAM and the negative control, Dan-PAMAM, was evaluated (Figure 5A,B). The maximum bacterial concentration was confirmed as a concentration in which aggregates could no longer be seen by the naked eye (S. aureus: $10^{7} \mathrm{CFU} \cdot \mathrm{mL}^{-1}$, E. coli: $10^{9} \mathrm{CFU} \cdot \mathrm{mL}^{-1}$ ).

(A)

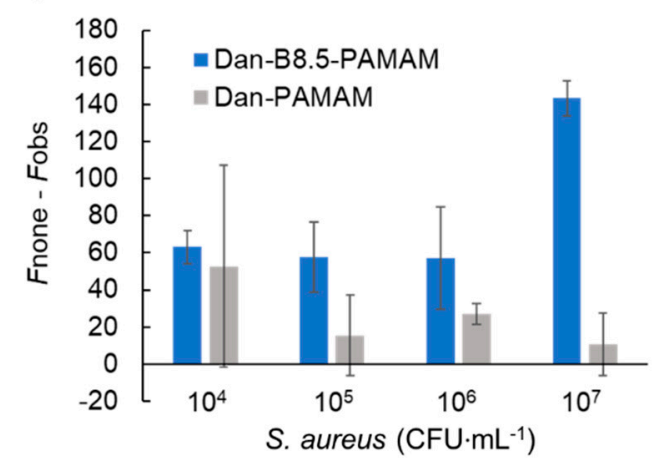

(B)

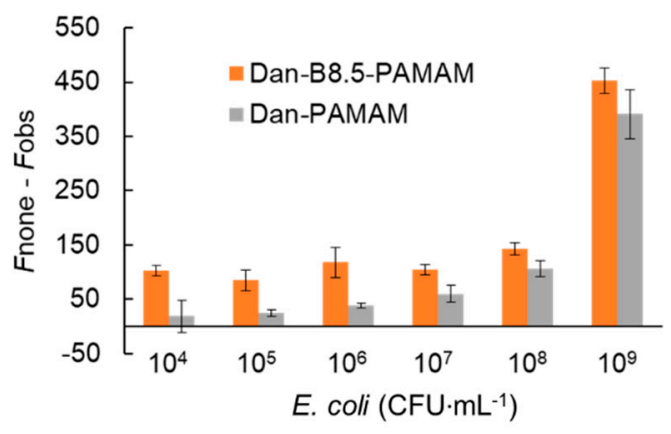

Figure 5. Summary of changes in fluorescence intensity $\left(\lambda_{\mathrm{ex}}=330 \mathrm{~nm}, \lambda_{\mathrm{em}}=522 \mathrm{~nm}\right.$, (probe) $=3.3 \mu \mathrm{M}$, $\mathrm{n}=3$ ). (A) (S. aureus) $=10^{4}-10^{7} \mathrm{CFU} \cdot \mathrm{mL}^{-1}$. (B) (E. coli) $=10^{4}-10^{9} \mathrm{CFU} \cdot \mathrm{mL}^{-1}$.

Only Dan-B8.5-PAMAM produced a significant reduction in fluorescence with both bacteria as expected (Table S3). Even in low concentrations of bacteria, Dan-B8.5-PAMAM successfully showed consistent performance with a small margin of error. Considering that Dan-PAMAM did not show significant changes in $10^{4}-10^{5} \mathrm{CFU} \cdot \mathrm{mL}^{-1}$ of bacteria, phenylboronic acid groups proved to be the origin of such sensitive recognition. Among high-concentration samples of E. coli, Dan-PAMAM demonstrated a significant reduction 
in fluorescence (Figure 5B). This could be explained by the Dan-PAMAM electrostatic interactions that formed minute aggregates. LOD was not calculated since linearity was not obtained for low concentrations. It was suggested that negligible operational errors affected the dispersion results, since the decrease in fluorescence was minor. Even though selectivity was not observed, this filtration protocol significantly improved the sensitivity of the turbidity method [31] (approximately $10^{3}$ times). It should be noted that the novel method could detect $10^{4} \mathrm{CFU} \cdot \mathrm{mL}^{-1}$ of bacteria and it met this requirement in some clinical settings [32,33].

\subsection{Viability of Bacteria}

In order to elucidate bacterial viability after the recognition procedure, S. aureus (which showed large aggregations, Figure 2C) was labeled by fluorescent compounds PI and AO. PI emits fluorescence when the bacteria surface is deconstructed, while AO shows both states of life and death. After the labeling, fluorescent microscopy images were obtained (Figure 6A).

\section{(A)}
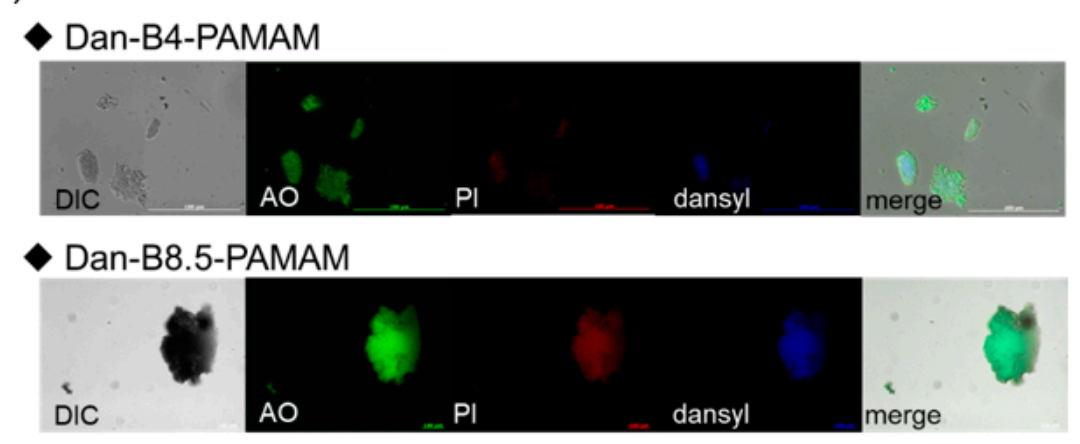

(B)

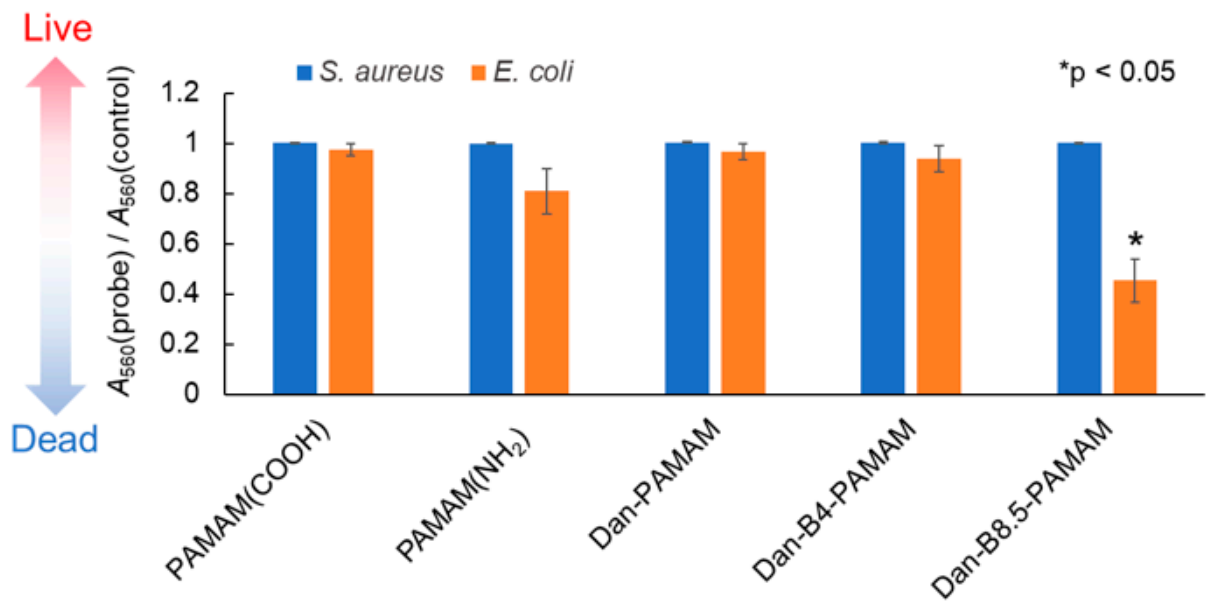

Figure 6. Viability of bacteria. (A) Fluorescence microscopy images of S. aureus $\left(10^{8} \mathrm{CFU} \cdot \mathrm{mL}^{-1}\right)$ incubated with a probe, $S$. aureus was stained with AO and PI, AO: $\lambda_{\mathrm{ex}}=500 \mathrm{~nm}, \mathrm{PI}: \lambda_{\mathrm{ex}}=530 \mathrm{~nm}$, probe: $\lambda_{\text {ex }}=330 \mathrm{~nm}$. (probe) $=3.3 \mu \mathrm{M}$. (B) Absorbance change by MTT assay repeated three times for each $\left(\lambda_{\mathrm{abs}}=560 \mathrm{~nm}\right),($ probe $)=3.3 \mu \mathrm{M},($ S. aureus $)=3.0 \times 10^{8} \mathrm{CFU} \cdot \mathrm{mL}^{-1},($ E. coli $)=3.0 \times 10^{8} \mathrm{CFU} \cdot \mathrm{mL}^{-1}$. Welch's t-test was used to compare control and probes. Differences were calculated with two-side test with an alpha level of 0.05 . Asterisks indicate significant differences $(p<0.05)$.

As the images clearly demonstrate, the fluorescent sites of AO, PI, and the dansyl group overlapped in both probes. This means that aggregates with damaged bacteria appeared independently of the concentration of phenylboronic acids. However, the existence 
of living bacteria was not confirmed because the areas of AO and PI overlapped. Hence, an MTT assay, which could provide information about bacteria's living ratio in a solution, was conducted (Figure 6B) [36]. In this assay, MTT was subjected to enzyme synthesis and formazan, with an absorbance at $560 \mathrm{~nm}$ being obtained. The absorbance of the control PBS sample was set as 1.0 and the absorbance ratio was calculated to give information about cell viability. When $S$. aureus was subjected to such an assay, almost all the bacteria were viable after the recognition protocol. Instead, over half of E. coli were dead in the case of Dan-B8.5PAMAM. Since the fluorescence microscopy images depicted the existence of damaged bacteria, the Dan-B-PAMAMs might interact with bacteria independently of bacterial status. Considering the results of PAMAM $\left(\mathrm{NH}_{2}\right)$ and Dan-PAMAM, bacterial selectivity was not observed due to amine groups or dansyl groups but from phenylboronic acid recognition sites. The relationship among the concentration of phenylboronic acids and the size of aggregates might be important because Dan-B4-PAMAM, with small aggregates, did not show any antibacterial activity. We hypothesized that, in the case of Dan-B8.5-PAMAM, E. coli suffered more because of the high density caused by large aggregates, and this caused the death of bacteria after recognition.

\section{Conclusions}

This report describes a fast, easy, and sensitive bacterial detection method which only takes $20 \mathrm{~min}$. Fluorescence-labeled PAMAM dendrimers with phenylboronic acid modification (Dan-B-PAMAMs) were designed and their interactions with bacteria were investigated. Especially in the case of Dan-B8.5-PAMAM fluorescence measurements, visible aggregates were obtained, and the sensitivity was significantly improved to $10^{4} \mathrm{CFU} \cdot \mathrm{mL}^{-1}$. The size of aggregates was dependent on the number of terminal phenylboronic acids on dendrimers, deemed to be the determinant for the increase in sensitivity. The major driving force of aggregation was provided by the interaction between phenylboronic acids and glycolipids situated on the surfaces of bacteria, rather than electrostatic interactions by the amino groups of dendrimer. Phenylboronic acids affected the viability of $E$. coli selectively, after its recognition. This report has provided new insights into the role of multipoint recognition which causes bacteria aggregation. Our results suggest that the size of bacteria aggregation is important, not only for recognition sensitivity but also for antibacterial activity. Even though the antimicrobial spectrum needs further investigation, this study may potentially be established as a method which provides convenient and sensitive detection and killing of bacteria.

Supplementary Materials: The following are available online at https:/ /www.mdpi.com/article/10 .3390/s21093115/s1, Figure S1: ${ }^{1} \mathrm{H}$ NMR spectrum of Dan-PAMAM, Figure S2: ${ }^{1} \mathrm{H}$ NMR spectrum of Dan-PAMAM, Figure S3: ${ }^{1} \mathrm{H}$ NMR spectrum of Dan-B3-PAMAM, Figure S4: ${ }^{1} \mathrm{H}$ NMR spectrum of Dan-B4-PAMAM, Figure S5: ${ }^{1} \mathrm{H}$ NMR spectrum of Dan-B8.5-PAMAM, Figure S6: Fluorescence measurements of control samples in PBS buffer pH 7.4, Figure S7: Examples of fluorescence spectra of the mixture between the probe and bacteria in PBS buffer $\mathrm{pH}$ 7.4, Figure S8: Fluorescence microscopy images of S. aureus with Dan-PAMAM, Table S1: Fluorescence intensity of control samples at $522 \mathrm{~nm}$ in PBS buffer pH 7.4 Table S2: Fluorescence intensity of Dan-B-PAMAMs in PBS buffer pH7.4 Table S3: Fluorescence intensity of the mixture between the probe and bacteria in PBS buffer pH 7.4 Table S4: Absorbance changes by MTT assay.

Author Contributions: Conceptualization and supervision, Y.T., T.H. (Takeshi Hashimoto) and T.H. (Takashi Hayashita); writing —original draft preparation, A.M.; writing—review and editing, T.H. (Takeshi Hashimoto) and T.H. (Takashi Hayashita); experiments, analyses and visualization, A.M. and R.T.; funding acquisition, A.M., Y.T., T.H. (Takeshi Hashimoto) and T.H. (Takashi Hayashita). All authors have read and agreed to the published version of the manuscript.

Funding: This work was financially supported by a Grant-in-Aid for JSPS Fellows (Grant No. 20J20891), a Grant-in-Aid for Early-Career Scientists (Grant No. 18K14255), a Grant-in Aid for Scientific Research (C) (Grant No. 18K05180) and a Grant-in Aid for Scientific Research (B) (Grant No. 20H02772) from the Japan Society for the Promotion of Science (JSPS). 
Institutional Review Board Statement: Not applicable.

Informed Consent Statement: Not applicable.

Data Availability Statement: Data sharing not applicable.

Acknowledgments: A JSPS Research Fellowship for Young Scientists (DC), awarded to A.M., is gratefully acknowledged.

Conflicts of Interest: The authors declare no conflict of interest.

\section{References}

1. Ventola, C.L. The antibiotic resistance crisis. Pharmacol. Ther. 2015, 40, 277-283.

2. Jones, K.E.; Patel, N.G.; Levy, M.A.; Storeygard, A.; Balk, D.; Gittleman, J.L.; Daszak, P. Global trends in emerging infectious diseases. Nature 2008, 451, 990-993. [CrossRef]

3. Reardon, S. Antibiotic resistance sweeping developing world. Nature 2014, 509, 141-142. [CrossRef]

4. Jacoby, G.A.; Archer, G.L.N. New mechanisms of bacterial resistance to antimicrobial agents. N. Engl. J. Med. 1991, 324, 601-612. [CrossRef] [PubMed]

5. Mandal, P.K.; Biswas, A.K.; Choi, K.; Pal, U.K. Methods for rapid detection of foodborne pathogens: An overview. Am. J. Food Technol. 2011, 6, 87-102. [CrossRef]

6. Lazcka, O.; Campo, F.J.D.; Muñoz, F.X. Pathogen detection: A perspective of traditional methods and biosensors. Biosens. Bioelectron. 2007, 22, 1205-1217. [CrossRef] [PubMed]

7. Swaminathan, B.; Feng, P. Rapid detection of food-borne pathogenic bacteria. Annu. Rev. Microbiol. 1994, 48, 401-426. [CrossRef]

8. Ray, P.C.; Khan, S.A.; Singh, A.K.; Senapati, D.; Fan, Z. Nanomaterials for targeted detection and photothermal killing of bacteria. Chem. Soc. Rev. 2012, 41, 3193-3209. [CrossRef]

9. Chen, J.; Andler, S.M.; Goddard, J.M.; Nugen, S.R.; Rotello, V.M. Integrating recognition elements with nanomaterials for bacteria sensing. Chem. Soc. Rev. 2017, 46, 1272-1283. [CrossRef] [PubMed]

10. Lqbal, S.S.; Mayo, M.W.; Bruno, J.G.; Bronk, B.V.; Batt, C.A.; Chambers, J.P. A review of molecular recognition technologies for detection of biological threat agents. Biosens. Bioelectron. 2000, 15, 549-578. [CrossRef]

11. Lay, J.O., Jr. MALDI-TOF mass spectrometry of bacteria. Mass Spec. Rev. 2001, 20, 172-194. [CrossRef] [PubMed]

12. Lim, S.H.; Mix, S.; Anikst, V.; Budvytiene, I.; Eiden, M.; Churi, Y.; Queralto, N.; Berliner, A.; Martino, R.A.; Rhodes, P.A.; et al. Bacterial culture detection and identification in blood agar plates with an optoelectronic nose. Analyst 2016, 141, 918-925. [CrossRef] [PubMed]

13. Skottrup, P.D.; Nicolaisen, M.; Justesen, A.F. Towards on-site pathogen detection using antibody-based sensors. Biosens. Bioelectron. 2008, 24, 339-348. [CrossRef]

14. Call, D. Challenges and opportunities for pathogen detection using DNA microarrays. Crit. Rev. Microbiol. 2005, 31, 91-99. [CrossRef]

15. Engvall, E.; Perlmann, P. Enzyme-linked immunosorbent assay (ELISA) quantitative assay of immunoglobulin G. Immunochemistry 1971, 8, 871-874. [CrossRef]

16. Wu, L.; Luan, T.; Yang, X.; Wang, S.; Zheng, Y.; Huang, T.; Zhu, S.; Yan, X. Trace detection of specific viable bacteria using tetracysteine-tagged bacteriophages. Anal. Chem. 2014, 86, 907-912. [CrossRef] [PubMed]

17. Nordmann, P.; Poirel, L.; Mueller, L.J. Rapid detection of fosfomycin resistance in Escherichia coli. Clin. Microbiol. 2019, 57, e01531-18. [CrossRef]

18. Kasai, Y.; Kobayashi, H.; Tsuchido, Y.; Hashimoto, T.; Kanzawa, N.; Hayashita, T. Staphylococcus aureus detection by fluorescent silica nanoparticles modified with metal-dipicolylamine complexes. Chem. Lett. 2016, 45, 749-751. [CrossRef]

19. Lee, J.-J.; Jeong, K.J.; Hashimoto, M.; Kwon, A.H.; Rwei, A.; Shankarappa, S.A.; Tsui, J.H.; Kohane, D.S. Synthetic ligand-coated magnetic nanoparticles for microfluidic bacterial separation from blood. Nano Lett. 2014, 14, 1-5. [CrossRef] [PubMed]

20. Leevy, W.M.; Lambert, T.N.; Johnson, J.R.; Morris, J.; Smith, B.D. Quantum dot probes for bacteria distinguish Escherichia coli mutants and permit in vivo imaging. Chem. Commun. 2008, 2331-2333. [CrossRef]

21. Qi, Z.; Bharate, P.; Lai, C.-H.; Ziem, B.; Böttcher, C.; Schulz, A.; Beckert, F.; Hatting, B.; Mülhaupt, R.; Seeberger, P.H.; et al. Multivalency at interfaces: Supramolecular carbohydrate-functionalized graphene derivatives for bacterial capture, release, and disinfection. Nano Lett. 2015, 15, 6051-6057. [CrossRef]

22. El-Boubbou, K.; Gruden, C.; Huang, X. Magnetic glyco-nanoparticles: A unique tool for rapid pathogen detection, decontamination, and strain differentiation. J. Am. Chem. Soc. 2007, 129, 13392-13393. [CrossRef]

23. Hayden, S.C.; Zhao, G.; Saha, K.; Phillips, R.L.; Li, X.; Miranda, O.R.; Rotello, V.M.; El-Sayed, M.A.; Schmidt-Krey, I.; Bunz, U.H.F. Aggregation and interaction of cationic nanoparticles on bacterial surfaces. J. Am. Chem. Soc. 2012, 134, 6920-6923. [CrossRef] [PubMed]

24. Liu, L.; Xu, K.; Wang, H.; Tan, P.K.J.; Fan, W.; Venkatraman, S.S.; Li, L.; Yang, Y.-Y. Self-assembled cationic peptide nanoparticles as an efficient antimicrobial agent. Nat. Nanotechnol. 2009, 4, 457-463. [CrossRef] [PubMed] 
25. Kell, A.J.; Stewart, G.; Ryan, S.; Peytavi, R.; Boissinot, M.; Huletsky, A.; Bergeron, M.G.; Simard, B. Vancomycin-modified nanoparticles for efficient targeting and preconcentration of Gram-positive and Gram-negative bacteria. ACS Nano 2008, 2, $1777-1788$. [CrossRef] [PubMed]

26. Kim, D.; Kwon, S.-J.; Wu, X.; Sauve, J.; Lee, I.; Nam, J.; Kim, J.; Dordick, J.S. Selective killing of pathogenic bacteria by antimicrobial silver nanoparticle-cell wall binding domain conjugate. ACS Appl. Mater. Interfaces 2018, 10, 13317-13324. [CrossRef]

27. Wu, S.; Duan, N.; Shi, Z.; Fang, C.C.; Wang, Z. Simultaneous aptasensor for multiplex pathogenic bacteria detection based on multicolor upconversion nanoparticles labels. Anal. Chem. 2014, 86, 3100-3107. [CrossRef]

28. Hibbard, H.A.J.; Reynolds, M.M.J. Fluorescent nitric oxide donor for the detection and killing of Pseudomonas aeruginosa. Mater. Chem. B 2019, 7, 2009-2018. [CrossRef]

29. Bull, S.D.; Davidson, M.G.; van den Elsen, J.M.H.; Fossey, J.S.; Jenkins, A.T.A.; Jiang, Y.-B.; Kubo, Y.; Marken, F.; Sakurai, K.; Zhao, J.; et al. Exploiting the reversible covalent bonding of boronic acids: Recognition, sensing, and assembly. Acc. Chem. Res. 2013, 46, 312-326. [CrossRef]

30. Wu, X.; Li, Z.; Chen, X.-X.; Fossey, J.S.; James, T.D.; Jiang, Y.-B. Selective sensing of saccharides using simple boronic acids and their aggregates. Chem. Soc. Rev. 2013, 42, 8032-8048. [CrossRef]

31. Tsuchido, Y.; Horiuchi, R.; Hashimoto, T.; Ishihara, K.; Kanzawa, N.; Hayashita, T. Rapid and selective discrimination of Grampositive and Gram-negative bacteria by boronic acid-modified poly(amidoamine) dendrimer. Anal. Chem. 2019, 91, 3929-3935 [CrossRef]

32. Orenstein, R.; Wong, E.S. Urinary tract infections in adults. Am. Fam. Physician 1999, 59, 1225-1234.

33. Schmiemann, G.; Kniehl, E.; Gebhardt, K.; Matejczyk, M.M.; Hummers-Pradier, E. The diagnosis of urinary tract infection. Dtsch. Arztebl. Int. 2010, 107, 361-367. [CrossRef]

34. Wang, B.-B.; Zhang, X.; Jia, X.-R.; Li, Z.-C.; Ji, Y.; Yang, L.; Wei, Y. Fluorescence and aggregation behavior of poly(amidoamine) dendrimers peripherally modified with aromatic chromophores: The effect of dendritic architectures. J. Am. Chem. Soc. 2004, 126, 15180-15194. [CrossRef] [PubMed]

35. Li, W.-S.; Teng, M.-J.; Jia, X.-R.; Wang, B.-B.; Yeh, J.-M.; Wei, Y. Synthesis and energy-transfer properties of poly(amidoamine) dendrons modified with naphthyl and dansyl groups. Tetrahedron Lett. 2008, 49, 1988-1992. [CrossRef]

36. Grela, E.; Kozlowska, J.; Grabowiecka, A. Current methodology of MTT assay in bacteria-A review. Acta Histochem. 2018, 120, 303-311. [CrossRef] [PubMed]

37. Suarez, I.J.; Rosal, R.; Rodriguez, A.; Ucles, A.; Fernandez-Alba, A.R.; Hernando, M.D.; Garcia-Calvo, E. Chemical and ecotoxicological assessment of poly(amidoamine) dendrimers in the aquatic environment. Trends Anal. Chem. 2011, 30, 492-506. [CrossRef]

38. Chen, W.; Li, Q.; Zheng, W.; Hu, F.; Zhang, G.; Wang, Z.; Zhang, D.; Jiang, X. Identification of bacteria in water by a fluorescent array. Angew. Chem. Int. Ed. 2014, 126, 13954-13959. [CrossRef] 